\title{
EFEKTIVITAS PENGEMBANGAN PERANGKAT PEMBELAJARAN MODEL PBL BERBANTUAN SIMULASI PhET PADA MATERI TERMODINAMIKA UNTUK MENINGKATKAN KEMAMPUAN BERPIKIR KRITIS SISWA
}

\author{
Alda Alvina Hawa1), Bambang Supriadi1), Sri Handono Budi Prastowo1) \\ 1)Pendidikan Fisika, Fakultas Keguruan dan Ilmu Pendidikan, Universitas Jember, Jember, Jawa Timur, Indonesia \\ Corresponding author : Alda Alvina Hawa \\ E-mail : alvinaalda89@gmail.com
}

Diterima 19 Agustus 2021, Direvisi 03 Agustus 2021, Disetujui 04 Agustus 2021

\begin{abstract}
ABSTRAK
Berpikir kritis menjadi hal yang diperlukan pada suatu pembelajaran, namun pada keadaan sebenarnya tidak semua sekolah menerapkan kebiasaan berpikir kritis. Seperti pembelajaran daring yang terjadi di masa pandemi Covid 19. Untuk meningkatkan kemampuan berpikir kritis siswa diperlukan adanya pengembangan pada perangkat pembelajaran. Tujuan penelitian ini adalah untuk mengetahui efektivitas pengembangan perangkat pembelajaran model PBL berbantuan simulasi PhET pada materi Termodinamika untuk meningkatkan kemampuan berpikir kritis siswa. Perangkat pembelajaran yang dikembangkan yaitu RPP, LKS, dan Soal dengan kemampuan berpikir kritis. Penelitian pengembangan yang memakai model ADDIE ini terdiri dari lima tahapan yaitu Analyze, Design, Development, Implement, dan Evaluate. Hasil penelitian menunjukkan bahwa pengembangan perangkat pembelajran model PBL berbantuan simulasi PhET pada materi Termodinamika efektif untuk meningkatkan kemampuan berpikir kritis siswa. Hal ini ditunjukkan dengan $\mathrm{N}$-gain score sebesar 55,69\% dengan kriteria sedang.
\end{abstract}

Kata kunci: Efektivitas; Perangkat Pembelajaran; Problem Based Learning; PhET; Berpikir Kritis.

\begin{abstract}
Critical thinking is a necessary thing in learning, but in reality not all schools apply the habit of critical thinking. Such as online learning that occurred during the Covid 19 pandemic. To improve students' critical thinking skills, it is necessary to develop learning tools. The purpose of this research was to determine the effectiveness of developing PBL model learning tools assisted by PhET simulation on Thermodynamics material to improve students' critical thinking skills. The learning tools developed are lesson plans, worksheets, and questions with critical thinking skills. The development research using the ADDIE model consists of five stages, namely Analyze, Design, Development, Implement, and Evaluate. The results showed that the development of PBL model learning tools assisted by PhET simulation on Thermodynamics material was effective in improving students' critical thinking skills. This is indicated by the $\mathrm{N}$-gain score of $55.69 \%$ with moderate criteria.
\end{abstract}

Keywords: Effectiveness; Learning Tools; Problem Based Learning; PhET; Critical Thinking

\section{PENDAHULUAN}

Pendidikan menjadi suatu usaha untuk memanusiakan manusia menjadi insan yang memiliki kecerdasan, kekuatan spiritual, kepribadian yang baik, dan keterampilan. Hal tersebut menyatakan bahwa pendidikan menjadi kebutuhan dasar yang diperlukan oleh manusia. Melalui pendidikan diharapkan dapat membentuk proses kulturasi yang menjadikan manusia untuk siap menghadapi perubahan zaman dan berkualitasnya Sumber Daya Manusia (SDM). Berkualitasnya SDM bisa dilihat dari bagaimana proses pendidikan itu dapat diterima oleh setiap manusia. Secara umum pendidikan adalah proses pembelajaran untuk mendapatkan pengetahuan dan keterampilan. Pembelajaran merupakan suatu langkah untuk dapat mengatur, mengorganisasi kondisi disekitar siswa sehingga bisa memotivasi untuk dapat melaksanakan proses belajar (Pane dan Dasopang, 2017: 337). Proses pembelajaran memiliki ciri utama yaitu terjadinya suatu interaksi antara guru dan siswa. Pembelajaran juga diartikan sebagai proses dimana transfer ilmu sedang berlangsung. Pada pembelajaran guru berperan sebagai orang yang mentransfer ilmunya, sedangkan siswa berperan sebagai penerima. Pembelajaran fisika menjadi proses belajar dan proses untuk bisa mengembangkan konsep, hukum, dan prinsip fisika secara ilmiah (Nuryanto, 2018: 10). Dalam pembelajaran 
fisika perangkat pembelajaran menjadi hal yang penting dan diperhatikan. Menurut Gunada dkk. (2015:38), pembelajaran yang berkualitas adalah tersedianya perangkat pembelajaran yang baik yaitu yang mampu membantu siswa sanggup mengetahui dan menguasai fisika. Dimasa pandemi Covid -19 ini mewajibkan guru untuk tetap menjalankan pembelajaran dengan situasi yang ada. Pembelajaran diharuskan untuk tetap berjalan agar pendidikan tetap terjamin. Maka dari itu guru diwajibkan untuk bisa kreatif dalam pembelajaran (Malyana, 2020:70). Menurut Hasibuan dkk menyatakan bahwa pembelajaran daring adalah suatu cara untuk mengatasi permasalahan pembelajaran saat ini. Pembelajaran daring yaitu metode belajar yang memakai model interaktif berbantuan internet dan Learning Manajemen System (LMS) contohnya Zoom, Google Meet, dan sebagainya, yang umumnya dilaksanakan dalam kelas online ataupun webinar dengan bantuan internet dan komputer (Malyana, 2020: 71). Adapun Luring, dalam KBBI dijelaskan bahwa luring memiliki arti luar jaringan atau terputus dengan jaringan. Jadi pembelajaran luring ini menggunakan buku pegangan siswa atau pertemuan secara langsung. Selain itu kegiatan luring lainnya adalah menonton TVRI (Malyana, 2020:71).

Kompetensi inti pada kurikulum 2013 menuntut pelaksanaan pembelajaran fisika menekankan pada pendekatan saintifik dengan harapan siswa lebih aktif dalam menemukan pengetahuan, keterampilan, spiritual dan sosial. Peran siswa sebagai subjek utama dan guru sebagai penyedia membantu tercapainya pembelajaran dengan kompetensi 2013. Model PBL yakni contoh model yang cocok pada pembelajaran fisika dan sesuai dengan kompetensi inti kurikulum 2013. Dari hasil penelitian Intandari dkk (2018: 350) menyimpulkan bahwa pembelajaran fisika dengan model PBL membuat peserta didik didalam kelas menjadi lebih aktif dan kritis menghadapi masalah pada pelajaran fisika. Model PBL ialah model yang bisa mendukung berpikir kritis karena didasarkan pada suatu masalah dan membangkitkan keingintahuan siswa (Nafiah dan Suyanto, 2014:130). Prinsip PBL yakni memberikan suatu problematika pada pembelajaran, masalah yang diberikan merupakan masalah yang acapkali ditemui dikehidupan sehari -hari (Amir, 2010).

Berpikir kritis adalah parameter berpikir tingkat tinggi, atau berpikir secara konvergen, logis, dan juga bernalar (Farisi dkk, 2017:284). Kemampuan berpikir kritis ialah kemampuan yang bisa diterima secara akal, rasional dan bertanggung jawab untuk menetapkan yang diyakini sehingga hasil dari berpikir kritis tersebut dapat menghasilkan kesimpulan yang terbaik (Sulardi dkk, 2015: 802 - 803). Pembelajaran dengan menggunakan berpikir kritis akan memberikan persiapan siswa untuk menghadapi masa depan. Materi yang diberikan guru tidak hanya digunakan untuk dihafalkan dan mendapatkan nilai namun berguna untuk mengenal arti dan kegunaan dari materi tersebut. Hasil dari berpikir kritis tadi apabila dihubungkan menggunakan pengetahuan yang diperoleh maka akan berguna dan bermanfaat bagi murid di masa depan (Sulardi dkk., 2015 :803). Seiring dengan berkembangnya zaman, kemampuan berpikir kritis sangat diperlukan. Namun pada keadaan yang sebenarnya kebiasaan untuk berpikir kritis belum diterapkan di banyak sekolah. Menurut Kurniawan, dkk (2015:123) metode konvensional atau ceramah masih sering digunakan oleh guru pada pembelajaran fisika yang cenderung membuat siswa menjadi bosan dan kurang memperhatikan disaat guru sedang menjelaskan. Proses pembelajaran yang kurang melibatkan siswa akan membuat siswa menggunakan sedikit kemampuannya (Setyorini dkk, 2011: 52). Oleh sebab itu, mata pelajaran fisika acapkali dianggap menjadi mata pelajaran yang sulit di sekolah (Samudra, dkk. 2014).

Termodinamika adalah subbab yang terdapat pada pelajaran fisika dan diketahui menjadi ilmu yang mempelajarai tentang kalor atau panas dan cara perpindahannya (Sudarmo dkk, 2018:197). Termodinamika merupakan proses dimana energy dipindahkan sebagai kalor dan usaha. Kalor didefinisikan sebagai perpindahan suatu energy akibat terjadinya perbedaan temperature, sedangkan usaha adalah perubahan energy yang tidak disebabkan oleh perubahan temperature. Termodinamika adalah salah satu materi yang sulit karena konsepnya yang abstrak, sulit divisualisasikan, dan kompleks. Biasanya materi ini disampaikan dengan mengembangkan model matematika abstrak dan grafik dua dimensi teks saja sehingga mengakibatkan situasi dimana siswa tidak dapat menerapkannya dalam situasi yang nyata (Jamuri dkk, 2015:124). Upaya yang bisa dilakukan dengan bantuan simulasi komputer. Media yang bisa dipakai salah satunya adalah $\mathrm{PhET}$, simulasi komputer yang membantu siswa dapat belajar secara interaktif dengan penemuan untuk dapat memahami konsep fisis (Krisdiana \& Supardi, 2015). Pembelajaran menggunakan PhET ini tidak membutuhkan biaya yang banyak, karena hanya membutuhkan sebuah komputer dan aplikasi PhET untuk dapat menjalankannya. Semua simulasi yang ada pada PhET dikembangkan 
dengan penelitian, sehingga sesuai dengan kejadian yang nyata dan konsep yang akan dibangun, selain itu PhET telah mengembangkan simulasi interaktif yang memberi keuntungan dimana terjadinya pembauran teknologi komputer kedalam suatu pembelajaran (Susanto, 2019: 4). Simulasi PhET dikembangkan untuk menyokong siswa memahami konsep secara visual. PhET dapat mensimulasikan dalam bentuk penggunaan grafis dan kontrol yang intuitif. PhET merupakan simulasi yang mudah digunakan dan dapat diterapkan didalam kelas. Dalam penggunaannya simulasi PhET ini juga bisa diakses secara online melalui web https://phet.colorado.edu (Sumargo dan Yuanita, $2014 \quad$ :120). Keuntungan menggunakan simulasi PhET ini adalah dapat melakukan percobaan fisika dengan ideal dimana tidak semua dapat dilakukan menggunakan alat yang sebenarnya. Harapan memakai simulasi PhET dalam termodinamika bisa membantu siswa lebih memahami dan menguasai materi termodinamika.

Penelitian ini dilakukan di SMAN 1 Gambiran. Penelitian yang dilakukan yakni untuk mengetahui efektivitas pengembangan perangkat pembelajaran yang dikembangkan oleh peneliti. Perangkat pembelajaran yang dikembangkan berupa RPP, LKS, dan Soal dengan kemampuan berpikir kritis. Berdasarkan wawancara pada salah satu guru fisika di SMAN 1 Gambiran, guru fisika belum pernah menerapkan perangkat pembelajaran dengan model PBL berbantuan simulasi PhET pada materi Termodinamika. Oleh sebab itu, penelitian dilaksanakan untuk mengetahui efektivitas pengembangan perangkat pembelajaran model PBL berbantuan simulasi PhET pada materi Termodinamika untuk meningkatkan kemampuan berpikir kritis siswa.

\section{METODE PENELITIAN}

Penelitian ini ialah jenis penelitian pengembangan atau Research and Development (R\&D). Penelitian ini bertujuan untuk mengetahui efektivitas pengembangan perangkat pembelajaran model PBL berbantuan simulasi PhET pada materi Termodinamika untuk meningkatkan kemampuan berpikir kritis siswa. Model yang dipakai adalah model ADDIE yang memiliki lima tahapan yaiyu Analysis, Design, Development, Implementation dan Evaluation (Cahyadi,2019:36).

Penelitian ini dilakukan di SMA Negeri 1 Gambiran pada siswa kelas XI MIPA 4 semester genap tahun ajaran 2020/2021. Penelitian ini dilakukan selama 1 bulan yaitu pada bulan April. Subjek penelitian yang digunakan sebanyak 23 siswa. Data yang diperoleh pada penelitian ini adalah nilai efektivitas. Saksono dalam (Irawan dan Febriyanti, 2016: 90) mengemukakan bahwa efektifitas merupakan tingkat kelekatan output yang dicapai menggunakan output yang diperlukan dari sejumlah input.. Untuk menentukan nilai efektifitas didapatkan dari hasil pretest dan posttest. Selanjutnya akan dihitung menggunakan $\mathrm{N}$-gain score. Untuk menghitung nilai keefektifitasan adalah sebagai berikut:

$$
\% g=\frac{S_{\text {post }}-S_{\text {pre }}}{S_{\text {maks }}-S_{\text {pre }}} \times 100 \%
$$

Keterangan:

$$
\begin{array}{ll}
\mathrm{g} & =\text { gain yang dinormalisasi } \\
\mathrm{S}_{\text {maks }} & =\text { skor maksimum (ideal) } \\
\mathrm{S}_{\text {post }} & =\text { skor tes terakhir } \\
\mathrm{S}_{\text {pre }} & =\text { skor tes awal } \\
& \text { Untuk menentukan kriteria nilai }
\end{array}
$$

\begin{tabular}{|c|c|}
\hline Klasifikasi N-gain Score & Kriteria \\
\hline $\mathrm{g} \geq 70 \%$ & Tinggi \\
\hline $30 \% \leq \mathrm{g}<70 \%$ & Sedang \\
\hline $\mathrm{g}<30 \%$ & Rendah \\
\hline
\end{tabular}
efektivitas dapat dilihat pada Tabel 1. Kriteria Ngain score:

Tabel 1. Kriteria N-gain score

\section{HASIL DAN PEMBAHASAN}

Penelitian pengembangan model ADDIE terdiri dari lima tahap, yang pertama adalah tahap Analyze atau analisis. Tahap analisis ini terbagi menjadi tiga analisis yaitu analisis kebutuhan, analisis kurikulum, dan analisis karakteristik siswa. Pada tahap ini dilakukan wawancara pada guru fisika di SMA Negeri 1 Gambiran. Analisis kebutuhan dilakukan untuk mengetahui perangkat pembelajaran yang digunakan yaitu RPP, LKS, dan Soal yang digunakan selama pembelajaran fisika. Peneliti menganalisis RPP yang digunakan pada pembelajaran. RPP materi termodinamika yang digunakan adalah RPP daring satu halaman yang digunakan untuk dua kali pertemuan. RPP berisi tentang satuan pendidikan, kelas, alokasi waktu, materi pokok, sub materi, tujuan pembelajaran, langkah langkah kegiatan pembelajaran, dan penilaian pembelajaran. Hal ini sesuai dengan Surat Edaran Mendikbud Republik Indonesia No 14 Tahun 2019 tentang Penyederhanaan Rencana Pelaksanaan Pembelajaran (RPP), dimana memuat prinsip RPP yang efektif, efisien, dan berorientasi pada murid. Selanjutnya analisis kebutuhan pada LKS. Guru fisika di SMAN 1 Gambiran menggunakan LKS cetakan Intan Pariwara. LKS cetakan Intan Pariwara berisikan 
tujuan pembelajaran, pendalaman materi, contoh soal, serta dilengkapi tugas praktikum. LKS ini juga dilengkapi dengan tugas praktikum mengenai Hukum I Termodinamika. Berdasarkan analisis yang telah dilakukan peneliti, tugas praktikum yang ada pada LKS tersebut sebenarnya dilakukan secara berkelompok namun diakhir langkah - langkah percobaan terdapat catatan jika kondisi sekolah sedang memberlakukan pembelajaran daring dapat dilakukan dengan bantuan orang tua. Hal ini menunjukkan bahwa tugas praktikum tidak bisa dilakukan secara mandiri. Sedangkan pada saat wawancara guru fisika kelas XI MIPA menjelaskan mengalami hambatan pada pemahaman siswa pada masa pembelajaran daring serta mengalami keterbatasan untuk melaksanakan praktikum fisika. Selanjutnya analisis pada soal yang digunakan pada pembelajaran. Soal yang digunakan oleh guru fisika adalah soal - soal yang sudah menggunakan indikator berpikir kritis.

Analisis selanjutnya adalah analisis kurikulum. Kurikulum yang dipakai oleh SMA Negeri 1 Gambiran adalah kurikulum 2013 yang telah disesuaikan dengan kondisi pandemi. Penyesuaian pada kurikulum 2013 yaitu peringkasan kompetensi dasar. Seperti pada materi termodinamika yang diringkas menjadi dua kompetensi dasar. Hal ini dilakukan karena pada pembelajaran dimasa pandemi terbatas dengan waktu sehingga materi lebih dimampatkan untuk bisa mencakup semua materi pada semester genap ini serta memudahkan siswa untuk bisa menguasai materi yang diberikan.

Analisis yang ketiga adalah analisis karakteristik siswa. Menurut Piaget remaja yang sudah memasuki usia 11 atau 12 tahun sudah memasuki tahap perkembangan kognitif, sehingga mampu berpikir secara sistemik dan alternatif untuk memecahkan masalah (Sit, 2012:91). Berdasarkan subjek penelitian yang digunakan yaitu siswa -siswi kelas XI SMA, rata - rata tahun kelahiran berada pada kisaran tahun 2003 - 2004, sehingga usia mereka saat ini berada pada kisaran 17 - 18 tahun. Selain itu, peneliti menganalisis dari hasil ulangan harian materi sebelumnya yaitu Gelombang untuk mengetahui nilai pengetahuan siswa. berikut hasil ulangan harian pada materi gelombang:

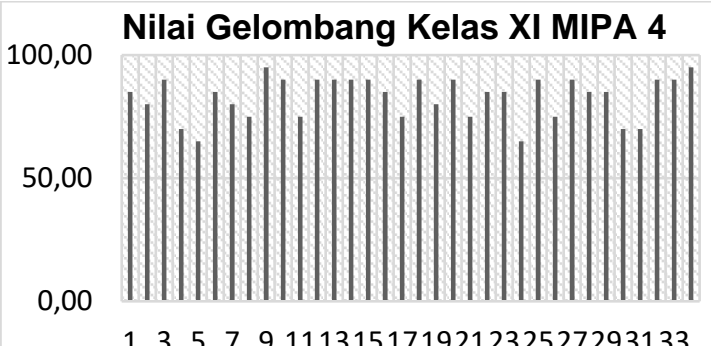

Gambar 1. Grafik Nilai Ulangan Harian Materi Gelombang

Berdasarkan nilai gelombang kelas $\mathrm{XI}$ MIPA 4 rata - rata seluruh siswa sudah mampu melampaui batas nilai KKM yaitu 70 hanya 2 orang siswa yang nilainya 65 , namun secara keseluruhan siswa sudah melampaui nilai KKM yang ditentukan. Dengan mempertimbangkan teori Piaget dan nilai ulangan harian pada materi sebelumnya maka siswa sudah mampu berpikir secara sistemik dan alternative dalam menyelesaikan masalah.

Selanjutnya tahap Design atau perancangan. Peneliti merancang RPP, LKS, dan Soal dengan kemampuan berpikir kritis berdasarkan hasil wawancara pada tahap analisis diawal. Peneliti merancang dua jenis RPP yaitu RPP luring dan RPP daring dikarenakan sekolah sudah menerapkan pembelajaran luring dan daring. Sehingga pembelajaran luring dilaksankaan pada minggu pertama dan pembelajaran daring dilaksanakan pada minggu kedua. RPP yang dikembangkan oleh peneliti terdiri dari Kompetensi Dasar (KD), Indikator, tujuan pembelajaran, media/ alat dan bahan sumber belajar, kegiatan pembelajaran, dan penilaian hasil belajar. Pengembangan yang dilakukan peneliti terdapat pada bagian kegiatan pembelajaran dimana peneliti menggunakan model PBL dan menggunakan bantuan simulasi PhET pada salah satu tahapan kegiatan pembelajaran yaitu investigasi. Kedua RPP memiliki tahapan yang sama hanya saja yang membedakan pada kegiatan pendahuluan. Hasil dari pengembangan RPP ini adalah RPP daring yang terdiri dua halaman dan RPP luring yang terdiri dua halaman juga. Selanjutnya peneliti merancang LKS Termodinamika dengan model PBL berbantuan simulasi PhET. LKS Termodinamika model Problem Based Learning berbantuan Simulasi PhET terdiri 18 halaman untuk dua kali pertemuan dengan ukuran A4. Bagian awal yaitu sampul LKS memuat judul LKS Termodinamika model Problem Based Learning berbantuan Simulasi PhET, jenjang pendidikan yaitu kelas XI SMA, kolom identitas siswa, dan nama penyusun LKS. Berikut adalah tampilan LKS yang 
dikembangkan oleh peneliti ditunjukkan oleh Gambar 1:

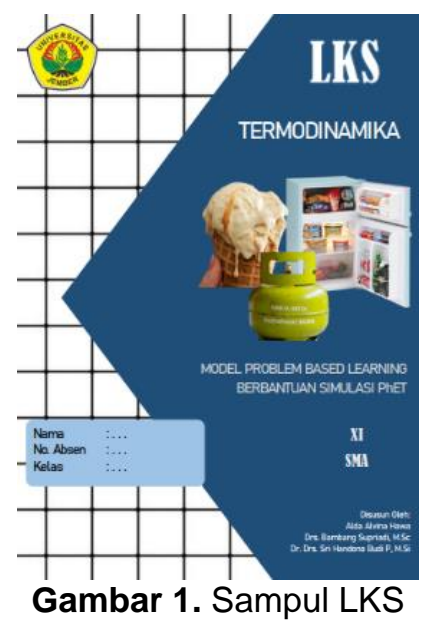

Kemudian pada halaman selanjutnya memuat Kompetensi Dasar (KD) dan Indikator Kurikulum 2013 Fisika SMA kelas XI materi Termodinamika, serta petunjuk pengerjaan LKS. LKS dirancang dengan susunan model PBL dan terdiri dari dua kegitan. Setiap kegiatan digunakan untuk satu kali pertemuan dan disertai dengan praktikum menggunakan simulasi PhET. Berikut adalah salah satu tampilan simulasi PhET pada LKS ditunjukkan oleh Gambar 2:

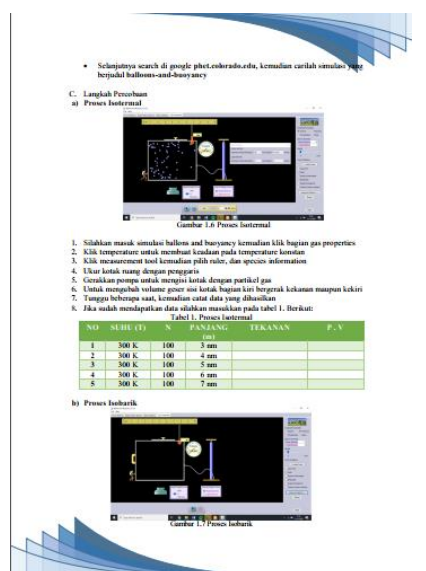

Gambar 2. Simulasi PhET pada LKS

Perancangan yang terakhir adalah soal dengan kemampuan berpikir kritis. Peneliti merancang soal yang dipakai untuk pretest dan posttest. Soal - soal terdiri dari 10 soal essay pretest dan 10 soal essay posttest. Soal dirancang memiliki indikator kemampuan berpikir kritis. sehingga diharapkan bisa meningkatkan kemampuan berpikir kritis siswa pada materi termodinamika. Selain itu, beberapa soal juga berkaitan dengan kegiatan simulasi PhET. Selanjutnya, soal soal yang diberikan kepada siswa juga memuat petunjuk pengerjaan.
Tahap yang ketiga adalah tahap Develop atau pengembangan. Tahap ini dilaksanakan validasi ahli dan validasi pengguna. Selain itu juga dilaksanakan uji terbatas untuk mengetahui kevalidan perangkat pembelajaran yang dikembangkan oleh peneliti. Validasi yang dilaksanakan adalah validasi RPP, validasi LKS, dan validasi soal dengan kemampuan berpikir kritis. Hasil validasi RPP menunjukkan skor rata - rata sebesar 4,00 dengan rentang penilaian $3,4<\tilde{x} \leq 4,2$ dan klasifikasi sikap baik. Sedangkan hasil validasi LKS menunjukkan skor rata - rata sebesar 4,03 dengan rentang penilaian $3,4<\tilde{x} \leq 4,2$ dan klasifikasi baik, dan hasil validasi Soal dengan kemampuan berpikir kritis menunjukkan hasil rata - rata sebesar 4,09 dengan rentang penilaian $3,4<\tilde{x} \leq 4,2$ dan klasifikasi baik. Dari hasil validasi perangkat pembelajaran yang dikembangkan sudah valid. Kemudian peneliti melakukan uji terbatas pada 6 siswa untuk mengetahui nilai efektifitas. Berikut hasil efektifitas pada uji terbatas:

Tabel 2. Efektifitas pada Uji Terbatas

\begin{tabular}{|c|c|c|c|c|}
\hline Komponen & Pretest & Posttest & $\begin{array}{l}\text { N-gain } \\
\text { Score }\end{array}$ & Kriteria \\
\hline Rata - Rata & 47,75 & 77,5 & \multirow{3}{*}{$56,93 \%$} & \multirow{3}{*}{ Sedang } \\
\hline $\begin{array}{l}\text { Skor } \\
\text { Tertinggi }\end{array}$ & 63 & 92 & & \\
\hline $\begin{array}{l}\text { Skor } \\
\text { Terendah }\end{array}$ & 40,5 & 62 & & \\
\hline
\end{tabular}

Berdasarkan Tabel 2. Efektifitas Uji Terbatas menunjukkan bahwa $\mathrm{N}$-gain score sebesar $56,93 \%$ dengan rentang penilaian $30 \%$ $\leq \mathrm{g}<70 \%$ dan kriteria sedang. Skor rata - rata pretest sebesar 47,75 dan skor rata - rata posttest sebesar 77,5 . Sedangkan skor tertinggi pretest sebesar 63 dan terendah 40,5 kemudian skor tertinggi posttest sebesar 92 dan skor terendah posttest sebesar 62. Perangkat pembelajaran yang dikembangkan peneliti memperoleh kriteria sedang atau dinyatakan cukup efektif untuk bisa meningkatkan kemampuan berpikir kritis siswa dikarenakan terjadi peningkatan nilai pada rata - rata skor pada pretest dan posttest. Seiring dengan penelitian yang dilaksanakan oleh Gusniar dan Juliani (2019: 14) terjadi peningkatan hasil belajar siswa sebesar $30 \%$ setelah diterapkan model PBL berbantuan media PhET. Berdasarkan hasil pada uji terbatas tersebut maka perangkat pembelajaran model PBL berbantuan simulasi PhET ini dapat diimplementasikan pada pembelajaran dikelas.

Tahap keempat adalah Implement atau implementasi. Setelah divalidasi dan diuji terbatas perangkat pembelajaran diimplementasikan pada 23 siswa kelas XI MIPA 4 SMA Negeri 1 Gambiran. Pada pertemuan yang pertama dilakukan pretest dan 
mengerjakan LKS untuk kegiatann 1. Kemudian pada pertemuan kedua siswa melakukan review pada kegiatan 1 dan dilanjutkan dengan mengerjakan kegiatan 2. Pada pertemuan yang ketiga dilakukan posttest. Hasil dari pretest dan posttest yang telah dilakukan maka dapat diperoleh nilai efektifitas pada kelas XI MIPA 4. Berikut hasil efektifitas pada kelas XI MIPA 4:

Tabel 3. Efektifitas pada Kelas XI MIPA 4

\begin{tabular}{|c|c|c|c|c|}
\hline Komponen & Pretest & Posttest & $\begin{array}{l}\text { N-gain } \\
\text { Score }\end{array}$ & Kriteria \\
\hline Rata - Rata & 35,28 & 71,32 & \multirow{3}{*}{$5,69 \%$} & \multirow{3}{*}{ Sedang } \\
\hline $\begin{array}{l}\text { Skor } \\
\text { Tertinggi }\end{array}$ & 57,5 & 92 & & \\
\hline $\begin{array}{l}\text { Skor } \\
\text { Terendah }\end{array}$ & 22 & 48 & & \\
\hline
\end{tabular}

Tabel 3. menunjukkan data hasil efektifitas perangkat pembelajaran model PBL berbantuan simulasi PhET untuk meningkatkan kemampuan berpikir kritis siswa pada kelas XI MIPA 4. Melalui tabel data tersebut dapat diketahui bahwa pada nilai pretest skor terendah sebesar 22 sedangkan skor tertinggi sebesar 57,5 sehingga rata - rata pretest yang didapatkan sebesar 35,28. Kemudian pada nilai posttest skor terendah sebesar 48 sedangkan skor tertinggi sebesar 92 sehingga didapatkan rata - rata posttest sebesar 71,32 . Terjadinya peningkatan nilai tersebut disebabkan karena siswa telah menggunakan perangkat pembelajaran model PBL dengan berbantuan simulasi PhET yang dikembangkan oleh peneliti. Setelah diketahui nilai pretest dan nilai posttest maka didapatkan $\mathrm{N}$-gain score sebesar $55,69 \%$ dengan rentang penilaian $30 \% \leq \mathrm{g}<$ $70 \%$ dan kriteria sedang. Perangkat pembelajaran dinyatakan cukup efektif dengan kriteria sedang diterapkan pada pembelajaran dikarenakan terjadi peningkatan pada nilai pretest dan nilai posttest. Terjadinya peningkatan ini dikarenakan siswa tertarik pada pembelajaran model PBL berbantuan simulasi $\mathrm{PhET}$. Selain itu pembelajaran berbantuan simulasi PhET ini adalah pengalaman pembelajaran yang baru sehingga siswa tetap bisa melakukan praktikum dan memahami konsep termodinamika walaupun pembelajaran dilakukan secara luring dan daring.

Tahap yang terakhir adalah tahap evaluate atau evaluasi. Pada tahapan ini peneliti melakukan analisis pada kesalahan yang terjadi selama proses penelitian. Kesalahan yang terjadi diantaranya adalah kesalahan penulisan pada LKS dan pemilihan kata yang digunakan. Selain itu juga terdapat kesalahan pada salah satu kunci jawaban sehingga peneliti perlu melakukan evaluasi kembali dan memperbaikinya.

Adapun kendala yang dihadapi selama penelitian yaitu waktu penelitian yang tidak dilakukan disaat jam pelajaran fisika. Hal ini disebabkan karena pembelajaran disekolah yang menggunakan sistem pembelajaran secara luring dan daring serta jam pelajaran yang terbatas sehingga jadwal pelajaran fisika juga terbatas. Namun hal ini dapat ditanggulangi dengan melakukan kesepakatan bersama siswa untuk melakukan penelitian diluar jam pelajaran fisika yaitu di jam sepulang sekolah. Setelah melakukan kesepakatan bersama, peneliti memohon perizinan kepada pihak sekolah untuk dilaksanakan penelitian pada jam sepulang sekolah. Sehingga penelitian tetap bisa dilaksanakan dan berjalan dengan baik. Kendala yang lain adalah tidak semua siswa dapat menginstal aplikasi pada handphone atau laptop mereka disebabkan karena keterbatasan memori pada handphone atau laptop sehingga peneliti harus mengelompokkan siswa yang tidak dapat menginstall simulasi $\mathrm{PhET}$ dengan siswa yang bisa melakukan install aplikasi. Namun hal ini tidak mengurangi keseriusan siswa pada pembelajaran dikarenakan semua siswa dapat menjalankan simulasi secara bergantian dan tetap menerapkan protokol kesehatan pada saat berlangsung.

\section{SIMPULAN DAN SARAN}

Berdasarkan hasil dan pembahasan dapat disimpulkan bahwa efektifitas pengembangan perangkat pembelajaran model PBL berbantuan simulasi PhET pada materi Termodinamika untuk meningkatkan kemampuan berpikir kritis siswa pada uji terbatas $\mathrm{N}$-gain score sebesar $56,93 \%$ sedangkan pada kelas XI MIPA 4 sebesar $55,69 \%$. Kedua nilai tersebut masuk kategori sedang, sehingga secara umum perangkat pembelajaran ini cukup efektif digunakan.

LKS yang dikembangkan peneliti dapat dilakukan pengembangan menjadi lebih baik dengan menambahkan simulasi proses adiabatic. Selain itu, perangkat pembelajaran model PBL berbantuan simulasi PhET ini dapat dikembangkan pada materi atau sub bab fisika lainnya. Perangkat pembelajaran model PBL berbantuan simulasi $\mathrm{PhET}$ ini juga bisa dijadikan solusi untuk melakukan pembelajaran dan praktikum pada kondisi pandemi saat ini. Sebelum memulai pembelajaran menggunakan simulasi PhET usahakan siswa sudah menginstal aplikasi simulasi PhET sehingga pembelajaran dapat berjalan sesuai waktu yang direncanakan. Selain itu sebelum dilakukan penelitian diusahakan untuk menetapkan jadwal agar penelitian dapat berjalan sesuai yang direncanakan.

\section{UCAPAN TERIMAKASIH}

Ucapan terima kasih peneliti 
apresiasikan kepada dosen - dosen pembimbing Pendidikan Fisika Universitas Jember. Selain itu peneliti sampaikan terima kasih kepada seluruh warga SMA Negeri 1 Gambiran karena telah berkenan menerima dan membantu selama penelitian berlangsung, serta kepada seluruh pihak yang telah membantu kelancaran penelitian ini

\section{DAFTAR RUJUKAN}

Cahyadi, R. A. H. (2019). Pengembangan Bahan Ajar Berbasis ADDIE Model. Halaqa Islamic Education Journal. 3(1):35 - 43..

Farisi, A., Abdul, H., dan Melvina. (2017). Pengaruh Model Pembelajaran Problem Based Learning Terhadap Kemampuan Berpikir Kritis dalam Meningkatkan Hasil Belajar Siswa pada Konsep Suhu dan Kalor. Jurnal IImiah Mahasiswa (JIM) Pendidikan Fisika. 2(3): $283-287$.

Gunada, I. W., H. Sahidu, dan Sutrio. (2015). Pengembangan Perangkat Pembelajaran Fisika Berbasis Masalah untuk Meningkatkan Hasil Belajar dan Sikap IImiah Mahsaiswa. Jurnal Pendidikan Fisika dan Teknlogi. 1(1): $38-46$.

Gusniar dan R. Juliani. (2019). Analisis Penerapan Model Pembelajaran Problem Based Learning (PBL) Berbantuan Media PhET di SMA Negeri 1 Pantai Cermin. Jurnal Ikatan Alumni Fisika Universitas Negeri Malang. 5(1):10 - 15 .

Intandari, R., S. Astutik., dan Maryani. (2018). Pengembangan LKS (Lembar Kerja Siswa) Berbantuan Simulasi PhET pada Materi Getaran Harmonis untuk Meningkatkan Keterampilan Berpikir Kritis pada Siswa SMA. Jurnal Pembelajaran Fisika. 7(4): 349 -355.

Jamuri, Kosim, dan A. Doyan. (2015). Pengaruh Model Pembelajran Kooperatif STAD Berbasis Multimedia Interaktif Terhadap Penguasaan Konsep Siswa Pada Materi Termodinamika. Jurnal Penelitian Pendidikan IPA (JPPIPA). 1(01): $123-134$.

Krisdiana, A., dan Z. A. I. Supardi. (2015). Penerapan Pembelajaran Guided Discovery pada Materi Fluida Dinamik deengan Media PhET untuk Meningkatkan Hasil Belajar Siswa Kelas XI SMA Negeri 1 Sooko. Jurnal Inovasi Pendidikan Fisika (JIPF). 04(02): $133-140$.

Kurniawan, T., J. Rokhmat., J. Ardhuha. (2015). Perbedaan Hasil Belajar Melalui
Penerapan Model Pembelajaran Berbasais Masalah Berbantuan Komik Fisika Dengan Pembelajaran Konvensional Pada Siswa Kelas VIII SMPN 1 Labuapi Tahun Ajaran 2013/2014. Jurnal Pendidikan Fisika dan Teknologi. 1(02): 123 -128.

Malyana, A. (2020). Pelaksanaan Pembelajaran Daring dan Luring dengan Metode Bimbingan Berkelanjutan Pada Guru Sekolah Dasar di Teluk Betung Utara Bandar Lampung. Jurnal IImiah Pendidikan Dasar Indonesia. 2(01):67 - 76.

Nafiah, Y. N dan W. Suyanto. (2014). Penerapan Model Problem Based Learning untuk Meningkatkan Keterampilan Berpikir Kritis dan Hasil Belajar Siswa. Jurnal Pendidikan Vokasi. 4 (1):125-143

Nuryanto, A. P. (2018). Pengembangan Perangkat Pembelajaran Fisika Berbasis Problem Based Learning untuk Meningkatkan Prestasi dan Minat Belajar Peserta Didik SMA. Skripsi. Yogyakarta: Fakultas Matematika dan IImu Pengetahuan Alam Universitas Yogyakarta.

Pane, A., dan M. D. Dasopang. (2017). Belajar dan Pembelajaran. FITRAH Jurnal Kajian IImu - IImu Keislaman. 03 (02): $333-352$.

Samudra, G. B., I. W. Suastra, dan K. Suma. (2014). Permasalahan - Permasalahan yang Dihadapi Siswa SMA di Kota Singaraja dalam Mempelajari Fisika. EJournal Program Pascasarjana Universitas Pendidikan Ganesha. 4(01).

Setyorini, U., S. E. Sukiswo, dan B. Subali. (2011). Penerapan Model Problem Based Learning untuk Meningkatkan Kemampuan Berpikir Kritis Siswa SMP. Jurnal Pendidikan Fisika Indonesia.7 :52 - 56 .

Simanjuntak, M.P. (2012). Peningkatan Pemahaman Konsep Fisika Mahasiswa Melalui Pendekatan Pembelajaran Pemecahan Masalah Berbasis Video. Jurnal Pendidikan Fisika. 1(2): 55 - 60.

Sit, M. 2012. Perkembangan Peserta Didik. Medan: Perdana Publishing.

Sudarmo, N. A., A. D. Lesmono, dan A. Harijanto. (2018). Analisis Kemampuan Berargumentasi IImiah Siswa SMA Pada Konsep Termodinamika. Jurnal Pembelajaran Fisika. 7(02):196 - 201.

Sulardi, M. Nur, dan W. Widodo. (2015). Pengembangan Perangkat Pembelajaran Fisika Model Problem 
Based Learning (PBL) untuk Melatih Keterampilan Berpikir Kritis Siswa. Jurnal Pendidikan Sains Pascasarjana Universitas Negeri Surabaya.5(1): 802 -810 .

Sumargo, E., dan L. Yuanita. (2014). Penerapan Media Laboratorium Virtual (PhET) pada Materi Laju Reaksi dengan Model Pengajaran Langsung. Unesa Journal of Chemical Education. 3(1): $119-133$.

Susanto, I. (2019). Pengaruh Model PBL Berbantuan PhET Terhadap Kemampuan Pemecahan Masalah Fisika pada Materi Pokok Elastisitas dan Hukum Hooke Siswa Kelas XI Semester I SMA Muhammadiyah 18 Sunggal T.P. 2019/2020. Jurnal Penelitian Fisikawan. 2(2): 1 - 7. 